\title{
Spatial Variability of Fruit and Seedling Growth of Mindi (Melia azedarach L.) in Community Forest, West Java, Indonesia
}

\author{
Laswi Irmayanti ${ }^{1^{*}}$, Iskandar Z.Siregar ${ }^{1}$, Prijanto Pamoengkas ${ }^{1}$
}

\begin{abstract}
${ }^{1}$ Department of Silviculture, Faculty of Forestry, Bogor Agricultural University, Jl. Lingkar Akademik, Darmaga Campus, Bogor 16680, Indonesia
\end{abstract}

\begin{abstract}
Mindi (Melia azedarach L.) is mostly found in community forests of West Java. Important factors affecting the productivity of community forests is the use of quality seed. However, seed quality is not easily available. Currently, community forests serve also as ad hoc seed sources that are usually without appropriate quality assessment. This research was aimed to determine baseline information on spatial variability of Mindi fruits collected from five seed sources, and seedling growths treated in seven different growing media consisting mixtures of soil, rice husk, sand, and cattle manure. Five Mindi populations were selected in the following villages: Nagrak (Bogor), Babakan Rema (Kuningan), Padasari (Sumedang), Sukakarya (Bogor) and Gambung (Bandung). The results showed that variability of seed dimension $(\mathrm{CV}=4.82-14.37 \%)$ and seedling growth $(11.79-21.77 \%)$ were moderate. The Mindi fruits from Nagrak were found to be the biggest in terms of size $(1.22 \pm 0.17 \mathrm{~cm})$, weight $(0.40 \pm 0.04 \mathrm{~g})$, and seed set $(85.47 \pm 15.09 \%)$. Besides, the seedling growth from Nagrak was also better than those of other villages showing its potential for future seed sources. Growing media containing cattle manure were observed consistently to be the best for seedling growth. The findings are useful in supporting the selection of seed sources from community forests scientifically.
\end{abstract}

Keywords: Mindi, community forest, growing media, seedling growth, seed source

\section{INTRODUCTION}

Mindi (Melia azedarach L.) is one type of alternative woods with high quality, and it is becoming hard to find and expensive due to the increasing market demand [1]. In crafting furniture industries in Jepara, Mindi wood is used as a substitute for teak wood when supply is reduced. Furthermore, its leaves, roots, bark and flowers can be used as medicines and natural pesticides [2].

Mindi is a type of plant that has good prospects for development in the community forests [3]. Mindi trees can adapt to different environmental conditions so that they can grow well in an extensive area [4]. Mindi community forest is one type of community forests where Mindis grow reasonably well and have a promising future, especially in West Java [5]. One of the factors that affect the productivity of the forest is the use of seed quality. However, seed quality is still

\footnotetext{
*Corresponding author:

Laswi Irmayanti

Department of Silviculture, Faculty of Forestry,

Bogor Agricultural University, Bogor 16680, Indonesia

E-mail: laswii88@gmail.com
}

difficult to obtain due to the limited number of seed sources.

Currently, the existence of community forests can serve as an alternative source of seeds. The selection of seed sources of community forests is general not properly assessed in terms of seed quality i.e. the seed physical, physiological and genetic qualities. The origin of the seed sources is one determinant of the quality of the seeds that are expected to produce good quality of seeds. However, information on the quality of the seed sources in the community forests is still lacking.

In respect to the above problems, it is necessary to conduct further research on seed quality through observations on spatial variability dimension of Mindi fruits and seedling growth from some community forests in West Java. This study aimed to estimate: (1) the spatial variability dimension of Mindi fruits collected from five different seed sources, (2) seedling growth in the nursery in seven different media from a mixture of top soil, sand, husk and compost. 


\section{MATERIALS AND METHODS}

Time and Location

The research was conducted starting from July 2013 to August 2014. The sample collection was carried out at five community forests in West Java including Bogor Regency (Sukaraja and Megamendung), Sumedang, Kuningan, and Bandung, as presented in Table 1. The activities of dimensional variability analysis of fruits and growth of seedlings were conducted at the nursery, Department of Silviculture, Faculty of Forestry.

\section{Materials and Instruments}

Tools and materials in this study were used to: 1 ) harvest the fruits, 2) extract the fruits, 3) measure the dimensions of fruits [6], 4) break dormancy, 5) produce seedlings, and 6) measure seedling growth. The growing media in the nurseries included a mixture of top soil, sand, husk, and manure.

\section{Fruit Dimension}

In general, the peak season of Mindi fruits starts from February to April [3]. The harvests of Mindi fruits were held in February 2014 and were taken from
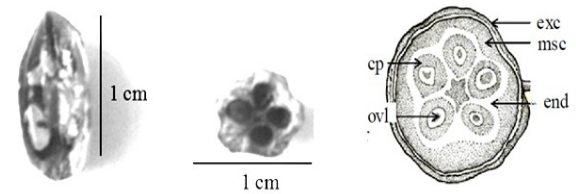

Figure 1. Cross-section of Mindi fruit, (a) Cross and longitudinal sections of Mindi fruit (personal photo), (b) part of Mindi fruit. ovl: ovule, cp: carpels, exc: exsocarp, msc: mesocarp, end: endocarp [7].

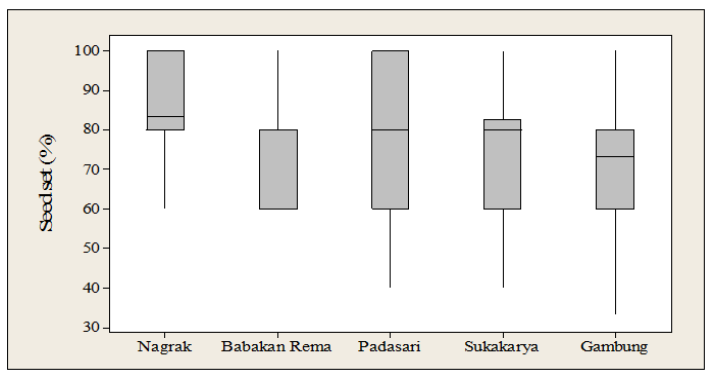

Figure 2. Distribution of Mindi's seed set at each location

Mindi Trees that had a healthy phenotype that would be served as the mother trees as suggested by Mulawarman [7].

Table 1. Details of sampled locations of Mindi plantation in West Java community [8]

\begin{tabular}{|c|c|c|c|}
\hline No & Location & GPS Coordinate & Altitude (m) \\
\hline 1. & Nagrak Village, Sukaraja Subdistrict, Bogor & 06o40’LS, 106 o53’ BT & 250 \\
\hline 2. & Babakan Rema Village, Kuningan Subdistrict, Kuningan & 06o45'LS, 105o20' BT & 417 \\
\hline 3. & Padasari Village, Cimalaka Subdistrict, Sumedang & 06o47’LS, 107o56’ BT & 490 \\
\hline 4. & Sukakarya Village, Megamendung Subdistrict, Bogor & 06o42’LS, 106 o54’ BT & 711 \\
\hline 5. & Gambung Village, Pasirjambu Subdistrict, Bandung & 07o14'LS, 107o51' BT & 1,250 \\
\hline
\end{tabular}

Table 2. Length and width of Mindi fruit at each location

\begin{tabular}{|c|c|c|c|c|c|c|}
\hline \multirow[t]{2}{*}{ Location $^{2}$} & \multicolumn{3}{|c|}{ Length } & \multicolumn{3}{|c|}{ Width } \\
\hline & $\begin{array}{c}\text { Mean } \\
(\mathrm{cm})\end{array}$ & $\begin{array}{c}\text { Range } \\
\text { (cm) }\end{array}$ & $\begin{array}{l}\mathrm{CV} \\
(\%)\end{array}$ & $\begin{array}{c}\text { Mean } \\
(\mathrm{cm})\end{array}$ & $\begin{array}{c}\text { Range } \\
\text { (cm) }\end{array}$ & $\begin{array}{l}\text { CV } \\
\text { (\%) }\end{array}$ \\
\hline Nagrak & $1.22 \pm 0.17^{2}$ & $0.75-1.64$ & 13.93 & $0.74 \pm 0.08^{2}$ & $0.55-0.96$ & 10.81 \\
\hline Babakan Rema & $1.19 \pm 0.13^{2}$ & $0.78-1.54$ & 10.92 & $0.70 \pm 0.07^{b}$ & $0.52-0.93$ & 10.00 \\
\hline Padasari & $1.21 \pm 0.19^{2}$ & $0.66-1.62$ & 15.70 & $0.73 \pm 0.08^{2}$ & $0.44-0.94$ & 10.96 \\
\hline Sukskarya & $1.13 \pm 0.19^{b}$ & $0.77-1.55$ & 16.81 & $0.70 \pm 0.07^{b}$ & $0.47-0.85$ & 10.00 \\
\hline Gambung & $1.12 \pm 0.13^{b}$ & $0.77-1.40$ & 11.61 & $0.70 \pm 0.08^{b}$ & $0.47-0.85$ & 11.42 \\
\hline
\end{tabular}

Table 3. The average value of Mindi fruits mass at each location

\begin{tabular}{|c|c|c|c|c|}
\hline \multirow[t]{2}{*}{ Location $^{x}$} & \multirow{2}{*}{$\begin{array}{c}\text { Moistare content } \\
\text { (\%) }\end{array}$} & \multicolumn{3}{|c|}{ Fruit mass } \\
\hline & & $\operatorname{Megn}^{x}(\mathrm{~g})$ & Range (g) & CV (\%) \\
\hline Nagrak & 15.40 & $0.40 \pm 0.04^{2}$ & $0.34-0.47$ & 10.95 \\
\hline Babakan Rema & 15.41 & $0.37 \pm 0.05^{2}$ & $0.31-0.47$ & 12.37 \\
\hline Padasari & 15.45 & $0.37 \pm 0.05^{2}$ & $0.31-0.46$ & 14.37 \\
\hline Sukskarya & 15.47 & $0.38 \pm 0.05^{2}$ & $0.35-0.46$ & 12.82 \\
\hline Gambung & 15.34 & $0.37 \pm 0.02^{2}$ & $0.35-0.39$ & 4.82 \\
\hline
\end{tabular}


Table 4. Recapitulation of GP (germination percentage), GV (germination value), and GS (germination speed).

\begin{tabular}{|c|c|c|c|c|c|}
\hline \multirow{2}{*}{ Observations time } & \multirow{2}{*}{ seed source $^{2}$} & \multirow{2}{*}{ GP (\%) } & \multicolumn{2}{|c|}{ GV } & \multirow{2}{*}{ GS } \\
\hline & & & Czabstor ${ }^{b}$ & Modified ${ }^{c}$ & \\
\hline \multirow[t]{5}{*}{$\mathrm{T}_{50}$} & Nagrak & 22.15 & 0.35 & 0.24 & 0.40 \\
\hline & Babakan Rema & 8.81 & 0.14 & 0.05 & 0.16 \\
\hline & Padasari & 8.08 & 0.14 & 0.03 & 0.14 \\
\hline & Sukakarya & 1.55 & 0.00 & 0.00 & 0.03 \\
\hline & Gambung & 2.00 & 0.00 & 0.00 & 0.04 \\
\hline \multirow[t]{5}{*}{$\mathrm{T}_{100}$} & Nagrak & 63.09 & 1.00 & 0.78 & 0.60 \\
\hline & Babaksan Rema & 29.41 & 0.44 & 0.21 & 0.28 \\
\hline & Padasari & 33.00 & 0.67 & 0.22 & 0.32 \\
\hline & Sukakarya & 27.91 & 0.12 & 0.07 & 0.27 \\
\hline & Gambung & 27.00 & 0.07 & 0.05 & 0.26 \\
\hline
\end{tabular}

Table 5. Analysis of variance of seed origin and combination of media on height and diameter growth of Mindi seeds

\begin{tabular}{|c|c|c|}
\hline \multirow[t]{2}{*}{ Source } & \multicolumn{2}{|c|}{$P<0.05$} \\
\hline & height & diameter \\
\hline Media & $0.0001^{\prime \prime}$ & $0.0001^{*}$ \\
\hline Replicates & $0.0820^{\mathrm{ns}}$ & $0.8715^{\mathrm{ns}}$ \\
\hline Seed source & $0.0287^{*}$ & $0.0029^{*}$ \\
\hline $\begin{array}{l}\text { Interaction between the media and } \\
\text { seed origin }\end{array}$ & $0.3471^{\mathrm{ns}}$ & $0.1989^{\mathrm{ns}}$ \\
\hline
\end{tabular}

The fruits were harvested based on the locations (Table 1) and the number of mother trees in the field. All of the collected fruits i.e. as many as 1,644 fruits were extracted in reference to Danu [9]. After the fruits had been dry, the measurement of fruit morphology including the length and width was conducted using a caliper, and measurement of fruit weight was carried out using a digital scale [10].
Measurement of the percentage of seed set was performed by splitting a fruit with the cross and longitudinal sections with a hammer, and the number of ovule and seeds in each fruit was calculated. From each mother plant, five pieces of fruits were collected and repeated for four times [11]. The equation for calculating the seed set referred to Hansen and Molau [12].

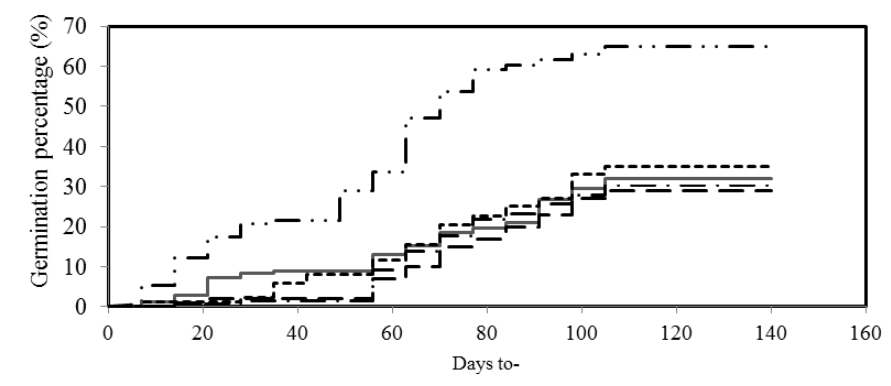

Figure 3. Observations on the number of germinating seeds until the end period of observations.

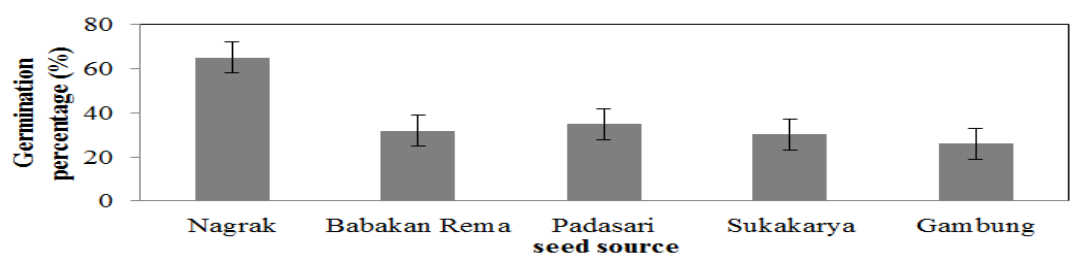

Figure 4. Germination percentage of Mindi from different seed source 


\section{Seedling}

The first step in the seedling is germinating the seeds. Seeds are sown in the sand medium $[9,13,14]$. Observations on germination were held for three months. The research was design used a split-plot design that referred to Mattjik and Sumertajaya [15] and Gomez [16] with a treatment in differences of seedling media and seed origin.

The seedling media treatments used in this study consisted of 7 kinds of media $[9,13,14]$, and the origin of seeds from 3 locations. The selection of the 3 locations was based on the number of seedlings sufficient for all treatments, i.e. from Nagrak, Babakan Rema, and Padasari. Each unit of the experiment was repeated three times so that the total experimental units were 63 units.

\section{Observations on Seed Growth}

Measurements of seedling growth variables that were conducted included the height and diameter [17]; [18]. The measurements of the seedlings' height and diameter were performed every month until they were four months old [14].

\section{Data Analysis}

Determination of physiological seed quality

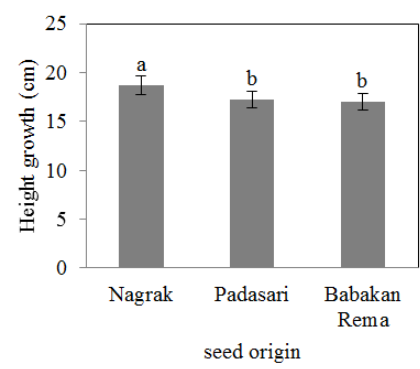

Figure 5. Height and diameter growth of Mindi seedling.

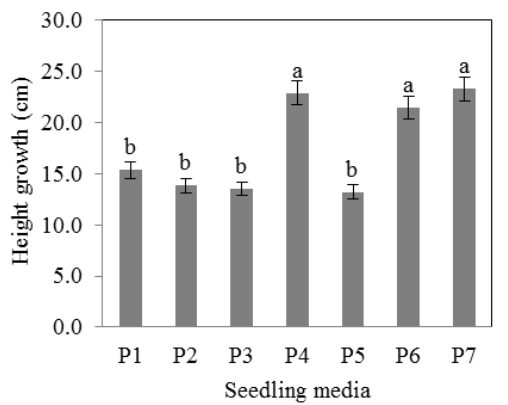

variables was conducted using Czabator equation, namely: GP (germination percentage), GV (germination value), and GS (germination speed) [1921].

The analysis of variance was used to examine the effects of treatment on the observed variables [15]. If a treatment significantly affects the measured variables, the multiple range tests (Duncan's test-DMRT) with the help of SAS 9.0 software [22] is performed. Data presentation was in the form of Boxplot using the software Minitab 15 [23].

\section{RESULTS AND DISCUSSION \\ Fruit Size}

Mindi is a type of stone fruit (drupe) [24]. The results showed that the average largest size of the fruits comes from Nagrak and Padasari. Length and width of Mindi fruits at each location are presented in Table 2.

In general, Table 2 shows that the higher the place, the smaller the fruit size. The fruits of Sukakarya and Gambung have a smaller size than those at other locations. From the altitude data, both locations have a higher elevation.

Research from Orwa [24] reported that Mindi can adapt to the altitude of $0-1,800 \mathrm{~m}$ above sea level. The
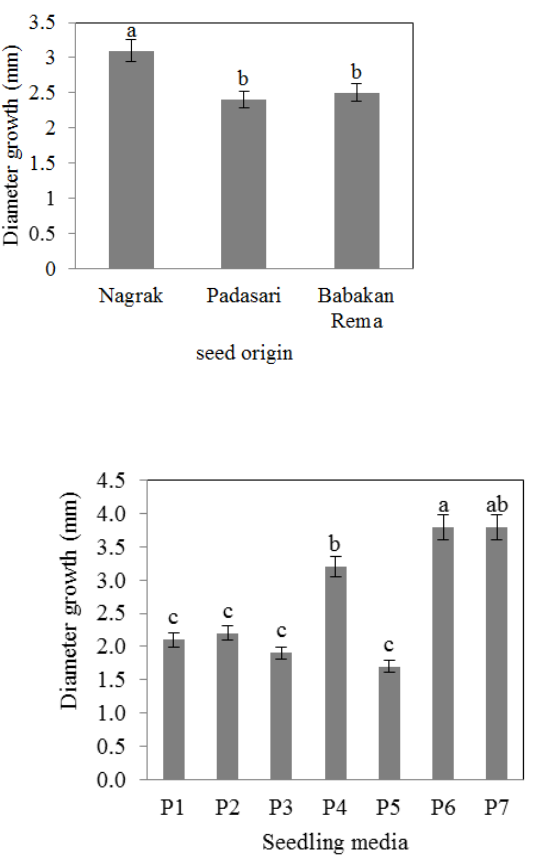

Figure 6. The influence seedling media on Mindi seedling growth, P1: soil, P2: soil + rice husk (3:1), P3: soil + sand (3:2), P4: soil + manure (3:1), P5: soil + rice husk + sand (3:1:2), P6: soil + rice husk + manure (3:1:1), P7: soil + sand + manure $\quad$ (3:2:1). The letters above the bar represent the midpoint between treatment comparisons based on Duncan test at

significance level 0.05 
small size of the Mindi fruits that come from Sukakarya and Gambung may be caused by the trees' low-temperature adaptation to the altitude of the locations.

\section{Fruit Mass}

The average Mindi fruit mass at each site was from $0.37 \mathrm{~g}$ to $0.40 \mathrm{~g}$. Fruit mass measurement results showed no significant differences at each location. If the mass is converted into many pieces of fruit each $\mathrm{kg}$, it will reach 2,500-2,700 pieces of fruits. According to Danu [9], the number of dried Mindi fruits is 1,286 pieces $\mathrm{kg}-1$, meanwhile, according to research [24], the number of fruits per $\mathrm{kg}$ is $470-2,800$ pieces. Therefore, it can be said that the measurement result of Mindi fruit mass in this study is still in the normal range. The measurement results showed that the heaviest fruits come from Nagrak site as presented in Table 3.

\section{Seed Set}

Seed set is the ratio of ovule toward the number of seeds [12]. Information of seed set can be used to predict the number of seeds for each $\mathrm{kg}$ of fruits. Cross and longitudinal sections of Mindi fruit are presented in Figure 1. The results showed that the average of the highest seed set is in fruits from Nagrak site (Figure 2). Tables 2 and 3 show that the coefficient of variation (CV) in the range of $4.82-14.73 \%$ fruit dimensions were categorized as moderate diversity [25].

\section{Germination}

The results showed that on day 112, all seeds did not have an additional percentage of seed germination marked with a line that began to be horizontal. Observations on the number of germinating seeds until the end period of observations are presented in Figure 4.

Figure 3 shows that the seeds of Nagrak and Padasari on day 7 started to germinate, followed by the seeds of Babakan Rema on day 14. On the 56th day, the seeds from Sukakarya and Gambung began to germinate. It can be seen from Table 2 that the seeds of Sukakarya and Gambung have a smaller size. Close and Wilson [26], Khan [11] and Kuniyal [6] reported that the seeds of the smaller and lighter fruits would have a longer germination rate compared with those of larger and heavier fruits.

The percentage of germination indicates the proper number of germination produced by seeds in a particular environmental condition. The germination percentage is usually used as a parameter of seed viability [27]. Of the five sources of seeds, the highest seed germination percentage comes from the fruits from Nagrak, reaching 65.10\% (Figure 4).

According to Rodrigues [27] and Sutopo [28] it is predicted that large and cumbersome seeds contain more food reserves, and their embryo is bigger than that of the small seeds. Khan [11] and Kuniyal [6] reported that the seeds of the small and light fruits will have a low germination percentage. Also, Khan [29] also reported that fruit mass is positively correlated with the percentage of germination; therefore, the heavier a fruit, the higher the germination percentage.

The results of this study indicate that the seeds of Nagrak have the highest values of GP, GV and GS of the other seeds (Table 4). If related to fruit size (Table 2 ), it is generally proportional to the values of GP, GV and GS, The larger the size of a fruit, the greater its values of GP, GV and GS.

\section{The Growth of Mindi Seeds}

Analysis of variance showed that the effect of seedling media is highly significant $(\alpha=0.05)$ on seedling height and diameter growth of Mindi seedling. However, the interaction between the media and seed origin is not significantly influential. Analysis of variance of seed source and combination of media on height and diameter growth of Mindi seeds is presented in Table 5. For CV values at the observation height and diameter growth of Mindi seedlings obtained by $11.79-21.77 \%$. Values of Mindi seedlings this study are categorized moderate variation [25].

\section{The Influence Seeds Origin on Mindi Seedling Growth}

The results showed that the largest increase in diameter and height for seeds occurred in seeds from Nagrak site. Duncan further test with $\alpha=0.05$ level shows that the height and diameter growth of seeds from Nagrak site are significantly different from those of Padasari and Babakan Rema (Figure 5). Blade and Vallejo [30] reported that seeds with greater size and mass will give a positive effect on the rapid increase in diameter and height as well growth of seeds. The highest fruit size and mass came from the seeds of Nagrak site (Tables 2 and 3). Figure 6 shows the maximum growth of the seeds from Nagrak site.

\section{The Influence Seedling Media on Mindi Seedling Growth}

The results showed that the $\mathrm{P} 4$ media (soil+manure) provides the relatively similar amount of height as the P6 media (soil + rice husk + manure) and the P7 media 
(soil + sand + manure) while for the growth in diameter, the P6 media is the best (Figure 6). Sudomo and Santosa [14] reported that a medium of soil and manure mixture provides largest height Mindi seedling because the manure application will ensure the availability of nutrients and improvement of medium aeration. EPA [31] reported that the nitrogen content of the manure is usually directly available to plants. Therefore, Mindi seedling will have larger height and diameter much faster in media containing manure.

\section{CONCLUSIONS}

The dimensional variability of Mindi fruits collected from five different sources of seed and their seedling growth in the nurseries are still relatively moderate. Mindi fruits of Nagrak have the largest size, weight, and seed set and the highest percentage of germination. The observations on the Mindi seed growth from different seed sources. The observations on seedling media show that the seeds of Nagrak have faster growth, compared with seeds from Padasari and Babakan Rema. The seedling media containing manure provide the most rapid growth.

\section{ACKNOWLEDGMENT}

Authors' gratitude and appreciation were presented to the Directorate General of Higher Education (Dikti) which had provided the Higher Education Scholarship for the fiscal year of 2012-2014 (attachment of Dikti letter No.2460/E4.4/2012).

\section{REFERENCES}

1. Syamsuwida D, Palupi ER, Siregar IZ, Indrawan A (2012) Flower initiation, morphology, and developmental stages of flowering-fruiting of Mindi (Melia azedarach L). JMHT. 18(1):10-17.doi: 10.7226/jtfm.18.1.10.

2. Karyono, Hariatno (2001) Opportunities and challenges of marketing Mindiwood (Melia azedarach L.): a case study in Bogor, West Java. J Socio-Economic. 2(2): 77-86.

3. Pramono AA (2012) Characteristics of the fruit season Mindi (Melia azedarach) in community forests in West Java. Seed Info. 16(2): 63-70.

4. Pramono AA, Danu, Rohandi (2012) Population distribution zone Mindi (Melia azedarach Linn.) In West Java and seed source potential stand. Seed Info. 16 (2): 5562.

5. Bramasto RGA (2011) Correlation between the production of Mindifruit grown (Melia azedarach Linn.) In West Java Community Forests [thesis]. Bogor Agricultural University. Bogor.

6. Kuniyal CP, Purohit V, Butola JS, Sundriyal RC (2013)
Seed size correlates seedling emergence in Terminalia bellerica. South African J of Botany. 87: 92-94.

7. Mulawarman, Roshetko JM, Sasongko SM, Irianto D (2002) Management of Tree Seed, Seed Sources, Seed Collection and Handling: Guidelines for Field Officers and Farmers Field. International Centre for Research in Agroforestry (ICRAF). Bogor.

8. Yulianti, Siregar IZ, Wijayanto N, Darma IGKT, Syamsuwida D (2011) Genetic variation of Melia azedarach in community forests of West Java assessed by RAPD. J Biodiversitas. 12(2): 64-69.

9. Danu (2005) Mindi (Melia azedarach). In: Rohandi D, Djam'an DF, Aminah A, Sitorus R, editors. Atlas Seed Woodland Plant Indonesia. Seed Technology Research Institute. pp 70-73. Bogor.

10. Kremer D, Karlovic K, Grubesic SJ (2009) Morphological variability of seeds and fruits of Ruscus hypoglossum in Croatia. Acta Biologica Cracoviensia. 51(1): 91-96.

11. Khan ML, Bhuyan P. Shankar U, Todaria N (1999) Seed germination and seedling fitness in Mesua ferrea L. in relation to fruit size and seed number per fruit. J Acta Oecologica. 20: 599-606.

12. Hansen JEL, Molau U (1994) Pollination biology, mating system, and seed set in a Danish population of Saxifraga granulata. Nordic J of Botany. 14(3): 257-268.

13. Mansur I (2010) Silviculture Technique for Mine Land Reclamation. SEAMEO BIOTROP. Bogor.

14. Sudomo A, Santosa HB (2011) Effect of organic and mineral soil media on the growth and seed quality index Mindin (Melia azedarach L.). J of Forest and Nature Conservation Research. 8(3): 263-271.

15. Mattjik AA, Sumertajaya IM (2013) Design of Experiments with Applications of SAS and Minitab. IPB Press. Bogor (ID).

16. Gomez KA, Gomez AA (2007) Statistical Procedures for Agricultural Research. Sjamsuddin E, Baharsjah JS, translator. UI Press. Translation from: Statistical Procedures for Agricultural Research. Jakarta.

17. Setyaningsih L (2007) Utilization of arbuscular mycorrhizal fungi and active compost to improve seedling growth Mindi (Melia azedarach Linn.) on gold mine tailings media Pongkor [thesis]. Bogor Agricultural University. Bogor.

18. [Ditjen RLPS] Directorate General of Land Rehabilitation and Social Forestry (2012) Forest Tree Seed Quality Standards. Directorate of Forest Tree Seed. Jakarta.

19. Caliskan S (2014) Germination and seedling growth of holm oak (Quercus ilex L.): effects of provenance, temperature, and radicle pruning. iForest. 7: 103-109. doi.10.3832/ifor0967-007.

20. Djavanshir K, Pourbeik H (1976) Germination value: a 
new formula. Silvae Genetica. 25: 79-83.

21. Gairola KC, Nautiyal AL, Dwivedi AK (2011) Effect of temperatures and germination media on seed germination of Jatropha curcas Linn.. Adv.Biores. 2(2): 66-71.

22. SAS Institute Inc (2006) Base SAS ${ }^{\circledR}$ 9.1.3 Procedures Guide Edisi ke-2. SAS Institute Inc. North Carolina.

23. Minitab Inc (2007) Meet Minitab 15 for Windows. Minitab Inc. USA.

24. Orwa C, Mutua A, Kindt R, Jamnadass R, Simons A (2009) Agroforestree Database: a tree reference and selection guide version 4.0. Agroforestry Database (4.0) [Internet]. [downloaded 2014 August 27]. Available at:http://www.worldagroforestry.org/treedb/AFTPDFS/Me lia_azedarach.pdf

25. Ginwal HS, Phartyal SS, Rawat PS, Srivastava RL (2005) Seed source variation in morphology, germination and seedling Growth of Jatropha curcas Linn. in Central India. Silvae Genetica. 54(2): 76-80.

26. Close DC, Wilson SJ (2002) Provenance effects on pre- germination treatments for Eucalyptus regnans and $E$. delegatensis seed. Forest Ecology and Management.170: 299-305.

27. Sutopo L (2012) Seed Technology. Rajawali Press. Jakarta.

28. Rodriguaes VG, Villar R, Cerrillo RMN (2011) Maternal influences on seed mass effect and initial seedling growth in four Quercus species. Acta Oecologica. 37: 1-9

29. Khan ML (2004) Effects of seed mass on seedling success in Artocarpus heterophyllus L., a tropical tree species of north-east India. Journal Acta Oecologica. 25: 103-110.

30. Blade C, Vallejo VR (2008) Seed mass effects on performance of Pinus halepensis Mill. seedlings sown after fire. J Forest Ecology and Management. 255:2362-2372. doi:10.1016/j.foreco.2007.12.039.

31. EPA [Environmental Protection Agency] (2007) The Use of Soil Amendments for Remediation, Revitalization, and Reuse. National Service Center for Environmental Publications. Cincinnati. 